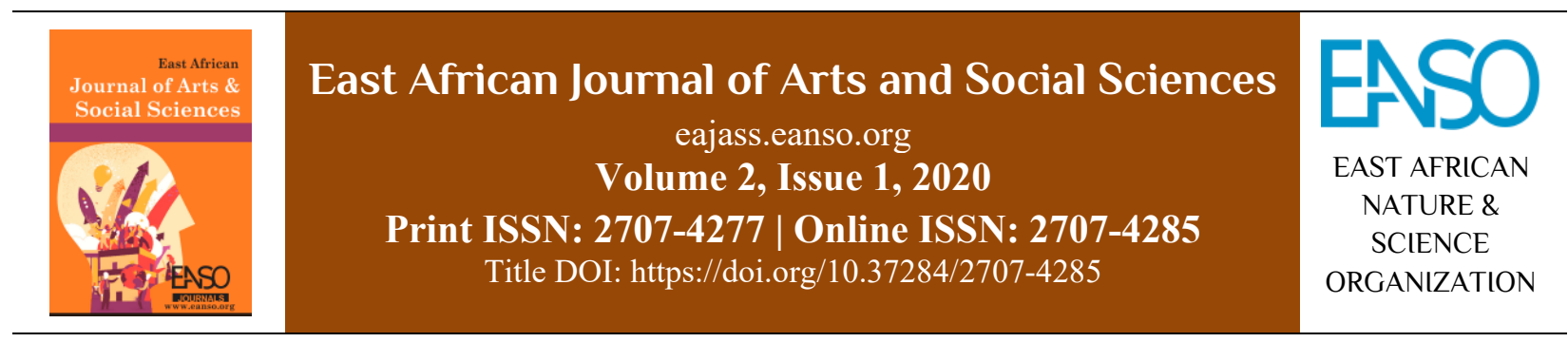

Original Article

\title{
Language Usage and Human Resource Performance in Local Governments in Uganda: A Case of Bududa District
}

\author{
Elizabeth Lamunul \& Dr. Willy Wanyenya, $P h D^{1^{*}}$ \\ ${ }^{1}$ Makerere University Business School, P. O. Box 1337, Kampala, Uganda. \\ *ORCID: https://orcid.org/0000-0002-7594-8256; Author for Correspondence email: wwanyenya@mubs.ac.ug.
}

Article DOI: https://doi.org/10.37284/eajass.3.1.271

\section{Article history: ABSTRACT}

15 February 2021 In this paper, the authors explain how language usage can affect human resource performance. They do that by explaining how language can be used in different

Keywords: institutions. Authors provide their explanations by referring to Bududa Local district government. The study's objectives were to explain the importance of

Language, human resources in organisations and the usefulness of language usage in human

Human Resource, Performance, Management, Organisations. resource performance. The research problem is that in Uganda, language usage has not been emphasised so much as a key element in human resource performance. In this study, the researchers used a case study and field research designs. By using this particular research design, they interviewed only a few people and the results were used to represent the whole District. The researchers used the staff in different departments as their respondents following their experience. The researchers tallied the data and gave the frequency of each role of language usage in human resource performance. After tallying the data, the results were presented by the use of tables. The study's findings are as follows: promoting unity among the employees, promoting love among the employees, giving employees the zeal to do the work, making the employees develop the spirit of belonging, and developing a collective responsibility spirit.

\section{APA CITATION}

Lamunu, E., \& Wanyenya, W. (2021). Language Usage and Human Resource Performance in Local Governments in Uganda: A Case of Bududa District. East African Journal of Arts and Social Sciences, 3(1), 24-34. https://doi.org/10.37284/eajass.3.1.271

\section{CHICAGO CITATION}

Lamunu, Elizabeth, and Willy Wanyenya. 2021. "Language Usage and Human Resource Performance in Local Governments in Uganda: A Case of Bududa District". East African Journal of Arts and Social Sciences 3 (1), $24-34$. https://doi.org/10.37284/eajass.3.1.271. 


\section{HARVARD CITATION}

Lamunu, E. and Wanyenya, W. (2021) "Language Usage and Human Resource Performance in Local Governments in Uganda: A Case of Bududa District”, East African Journal of Arts and Social Sciences, 2(1), pp. 24-34. doi: 10.37284/eajass.3.1.271.

\section{IEEE CITATION}

E. Lamunu, and W. Wanyenya, "Language Usage and Human Resource Performance in Local Governments in Uganda: A Case of Bududa District”, EAJASS, vol. 3, no. 1, pp. 24-34, Jan. 2021.

\section{MLA CITATION}

Lamunu, Elizabeth, and Willy Wanyenya. "Language Usage and Human Resource Performance in Local Governments in Uganda: A Case of Bududa District”. East African Journal of Arts and Social Sciences, Vol. 3, no. 1, Jan. 2021, pp. 24-34, doi:10.37284/eajass.3.1.271.

\section{INTRODUCTION}

Human resources refer to the employees of a company or an organization. According to the HumanResourcesEdu (2021), the term human resource first came into existence in the 1960s. This was the time when entrepreneurs began paying attention to the importance of workers in the performance of an organization. The recognition of the workers' role in the performance of a company made entrepreneurs come up with various forms of innovations in order to increase productivity.

Human resource management simply means overseeing employees to ensure that they perform their tasks to the best and also get professional growth and development. It is commonly known as personnel. Human resource management deals with all things concerned with managing the employees in a company or an organization. Given the importance of human resources in organisations, every effort must be made to improve its performance. For this reason, the authors investigated the effect of language usage on human resource performance in the local District governments in Uganda.

\section{RESEARCH PROBLEM}

According to the authors' perspective, in Uganda, the language used to improve human resource performance has not been so much emphasised. When it comes to improving human resource performance, people usually talk about welfare, allowances, salary increment, study scholarships to staff etc. Rarely do people talk about language usage in improving human resource performance. This, therefore, leaves a gap that the researchers aimed to fill in this study. The researchers aimed to explain how language usage can help improve human resource performance in local district governments in Uganda.

\section{REVIEW OF RELATED LITERATURE}

According to a report by Impraise (2020), although people have not realised it, language has a lot of impact on the organization's culture. The language used in a company or an organization works as a guide for the workers. The employees get to know the type of language required at their place of work and they stick to that. That is why employees of different organizations behave differently. It is due to the established culture which has been shaped by language usage. This is because language influences the way people think, act and feel in different situations. Impraise (2020) further says with an established culture, the employees can criticize anyone of them who acts contrary to the set norms. For example, different schools have different cultures and both students and employees are supposed to observe that culture. It is for this reason that employers may prefer people from particular institutions to the rest.

The mottos and statements put up by the authorities in different organizations are meant to guide the relevant community be it a school, University, Bank, insurance company etc. By doing this, HR and the executive are able to shape the culture of their institution. According to the same report, language has a lot of effect on the employees. It does 
not only shape the peoples' behaviour but also impacts the types of processes and company rituals (Impraise, 2020). Furthermore, it changes the way people feel about work. It is true that peoples' behaviour and feelings can affect the performance of a company either negatively or positively. If the workers have good behaviour and feelings about the company, they will work towards achieving the set goals hence maximizing the output. But if they have bad behaviour and feelings about the company, they will always try to fail it. They can do that by stealing from the company, spread false propaganda and engage in strikes.

Piekkari and Tietze (2020) look at the role of language in human resource performance from the perspective of attitude, social perception, personal identity, attribution and intergroup relations. According to these two scholars, language shapes and influences people's attitudes, social perception, personal identity, attribution, and intergroup relations. He says that language can promote international business (IB) given its importance in social functioning (Piekkari, Welch, \& Welch, 2014). These scholars say that studies carried out by individuals have investigated many other issues including foreign language anxiety and its influence on individual task performance in global virtual teams (Presbitero, 2020). He also says that language influences the social capital of multilingual employees as quoted by (Barner-Rasmussen et al., 2014).

The two scholars reaffirm that it is true that people have studied language from an International Business and organisational behaviour perspective. However, not much is known about the role of language in international human resource management (IHRM). According to these two scholars, early researches have shown the importance of being keen on language when recruiting and promoting employees as quoted by (Peltokorpi \& Vaara, 2017; 2014); Language training (Peltokorpi, 2017), and how language skills influence employees' career mobility (Itani et al.,
2015; Latukha et al., 2016; Pudelko \& Tenzer, 2019). Studies have also explored linguistic influences on expatriates' cross-cultural adjustment (Selmer \& Lauring, 2015; Zhang \& Peltokorpi (2015) Froese, Kim \& Eng, 2016). Although many scholars have addressed the issue of language in human resource performance, it is clear that there are realities which employees face on the ground which need to be addressed (Neeley, 2017, p. 5). Piekkari and Tietze (2020) continue to say that because of that, there is a need for more research to be carried out in order to understand better the role of language in human resource management. It is for this reason that the authors undertook this study so as to explain how language usage affects human resource performance in Uganda.

According to Jones (2010), language usage is key to human resource. Language determines how the function of HR is perceived. This scholar says that for HR to function properly, there is a need for the company to have the capacity to influence the behaviour of managers and their impact on staff. This particular scholar says that one area of particular concern is performance management, which is typically seen as a key function within the HR system of an organisation. The scholar says that there is need for HR to change how performance is nurtured, developed and improved. According to this scholar, the starting point in this process is the language used. Unfortunately, however, according to the authors, language has not been emphasized in Uganda as far as human resource performance is concerned. According to this scholar, there is need to relocate performance within a life-cycle of talent development where the focus is on matching individual capability and competency to organisational growth and objectives.

According to a report by Summa Linguae Technologies (n.d.), a company with employees who do not speak English, human resource needs to provide translation services. The translation services help the human resource to work towards achieving the set goals despite language differences. 
The report emphasizes having translation policies. This is because writing employee manuals, information, documents, newsletters and videos requires effective translation. According to the report, the translation of documents needs to be done with accuracy to avoid confusion and indiscretion. The report shows that HR Translation Services is essential to overcome language barriers in a global organisation with a multilingual and multicultural workforce.

In a global scenario, language undoubtedly impacts business operations and their results. Language translation improves employee engagement and retention. Achieving goals becomes a more significant challenge with language barriers. It also affects the organisation's compliance and regulations. Effective HR translation service increases communication effectiveness, employee performance, job satisfaction, a better understanding of processes, and employee retention. When an organisation makes an effort to train its employees in their native languages, it ensures the right understanding of the organisational policies and shows that the organisation cares about the employee's growth and development.

According to McMunn (2017), the success of a company involves several factors which include great leadership, innovation, strong financial management, a well-defined vision and many others. He continues to say that companies aiming for global reach should prioritise strategies with quantitative and qualitative benefits for their workforce and customers. He says that perhaps an essential and tactical approach that organisations often overlook is language training. According to this scholar, a 2016 study by Rosetta Stone shows that while $81 \%$ of the employees surveyed studied languages earlier in life, only $46 \%$ effectively used their learnings in the workplace.

According to this scholar, foreign language skills are vital in today's global economy. McMunn (2017) says that language proficiency supports executives to advance in their careers and helps multinational companies to speed up overseas expansion. He says every CEO or HR manager who wants to hire a language trainer struggles to quantify the value and benefit of language training to the business. McMunn (2017) says that workers who receive language training become more confident and perform better.

McMunn (2017) says that people who complete language training successfully usually feel more comfortable at their places of work. This is because they have confidence when communicating with others. This scholar explains that the people who benefit most from these training schemes are those working in foods and beverages, retail and communications industries. McMunn (2017) further says that employees in human resources, information technology and operations departments have confirmed that they are now confident and work productivity has increased because of the language training they received.

According to this scholar, it has been reported that workers usually save on average three hours or more weekly as a result of their improved language skills. The scholar claims that the wasted hours were possibly being spent on language translation or resolving problems caused by miscommunication amongst colleagues or between employees and their bosses. McMunn (2017) says that language proficiency is important to every worker regardless of whether one is a line-level worker or an expert leading regional operations. According to this author, language proficiency improves employees' productivity and overall job performance.

McMunn (2017) further says that the confidence and increased productivity these people experience directly lead to promotions and upward mobility within the organisation or new job opportunities. He continues to say that work is usually affected when a newly hired person does not speak the language of the team. The employee may have a problem establishing rapport with colleagues and building 
trust with supervisors. He may tend to isolate himself or herself. However, employees who are given language training feel comfortable and confident because they speak the same language. As a result, they work as a team, chat with each other and plan together. This kind of environment leads to increased productivity thereby making the company grow. According to this scholar, for companies which operate globally to gain momentum in their business, there is need to speak the customers' language. It is, therefore, necessary for a company which operates in different countries to employ people who can talk to customers in various languages. Companies which want to capture the market should consider the target customers' local language. This is because the language will be used in promoting the business, acquire and retain customers. This, therefore, means multinational companies have to invest in learning local languages in places of operation.

According to a report by Human Resource Online (2018), there are several studies which have focused on how the language spoken in an organisation affects its corporate future orientation, and practices. According to that report, those studies were guided by the Sapir-Whorf hypothesis. Basing on that hypothesis, language greatly influences people's behaviour. It also influences their way of thinking. The studies have found out that companies which have strong future-time reference (FTR) languages like English, French and Spanish as their official language have less of a corporate future orientation whereas those in the weak-FTR language like German environments don't. In addition, companies which have strong FTR languages as their working language engage less in CSR and R\&D by $7 \%$ and $40.6 \%$ respectively, as compared to those in weak-FTR language environments. Studies have also found out that this effect is weakened when the company has greater exposure to multilingual environments, such as operating in a more linguistically diverse and globalised country and having more foreign institutional ownership.

According to Crowley (2017), language usage differs greatly across the globe. He says what is mentioned in one language may be translated differently in another language. These differences in translation make it hard to transact business. To this scholar, this has been a major problem for international HR. It is very important to translate ones' communication in a way that the entire workforce is able to understand. If communications are not translated properly, there may arise problems of misunderstandings.

According to Crowly (2017), communications with critical information should be perfectly translated. He says it is common for poorly translated communications to be sent out. He says this is not a big problem so long as the communications do not contain critical information. However, those with sensitive messages must at all cost be translated properly. For example, if a company has an important HR policy that needs to mean the same thing, word for word, across all regions of operation, then a miscommunication could lead to very serious problems. For example, one can be sued in courts of law. Secondly, company announcements should be properly translated to avoid confusion and misunderstandings. This is necessary especially if one has employees who work in different regions where various languages are spoken. Should this be the case, one must take care to ensure announcements are properly translated. Thirdly, if a company has established a system of communication using software, it is necessary that different languages are considered. This is to enable employees who speak different languages to understand the message being communicated. If this is not done, some people may not understand the message hence confusion and misunderstandings.

According to an article by Richard (2019) of the London School of English Language and Foreign 
Languages, human resource managers usually face a problem of understanding the language to use. This is because every field has its language. For example, footballers, engineers, doctors, lawyers have a language they use. That language is understood within the group. So, HR managers face a challenge of understanding the language to use. The matter is made worse as they deal with people from different backgrounds. They have to appraise employees, interview applicants for the advertised jobs, dismiss employees etc. So, in all these situations, the HR manager has to select words carefully to use in his communications. For example, in the case of dismissal, the use of a good language can make the dismissed person go away with hope. The person will keep remembering the HR manager as a good person. This is because before handing over a letter of dismissal, a good HR manager will first counsel the person. However, a bad HR manager will arrogantly call the dismissed person to sign for his/her letter without knowing what it is about. Such a person will walk away without hope and will curse that HR manager throughout life. Even if the person succeeds in getting another job the other experience will not go away. That HR manager will always remain a point of reference.

According to Brannen et al. (2014), language is very crucial in international business but it has not been given full attention by the researchers. These scholars say that it is only recent that language has become a point of focus. Many people have begun to see language as an important element in international business. They have come to realize that language affects everyday operations in business across the world. This, therefore, means that researchers should intensify research into the role of language in business.

Tenzer et al. (2017) say that although scholars have been carrying out research for the past few years on the role of language in international business, there is a lot more to be done. They claim that people have not yet understood the role of language in business.
This, therefore, calls for more studies to be carried out on the function of language in business transactions. This is the same reason which made the authors undertake this study in order to explain the role of language in human resource performance in Local District governments in Uganda.

\section{THEORETICAL FRAMEWORK}

This study was guided by the politeness theory which was put forward by Daniel Van Olmen in 2017. According to this theory, linguistic politeness refers to the proper usage of language so as not to offend others. In a community, it is common for some people to offend others by use of language considered to be inappropriate. At places of work, people may quarrel bitterly resulting from language usage. The authors, therefore, found this theory relevant to their study because language usage is paramount in human resource performance. To manage human resources, there must be proper language usage by employers. This theory guided the researchers, particularly in developing interview questions that generated the data presented in this paper.

\section{RESEARCH DESIGN}

In this study, the researchers used a case study and field research designs. Using these particular designs, the researchers went to the field and selected some respondents whom they interviewed. The researchers used random sampling to get the respondents. The respondents were interviewed according to departments. Each researcher handled particular departments at the District Headquarters. The researchers did not move to the departments together. They divided the departments between themselves. They did that to ease their work. At the end of the exercise, they put together the data which had been collected from the different departments. After the data had been put together, it was sorted. Unwanted data was removed and only required data was retained. After sorting had been done, data was rearranged according to the objectives. After that, the data was then tallied and frequencies given. The 
data was then presented in form of a table. The researchers preferred the interview method to the rest because it was easy to administer. Secondly, the researchers used this method of data collection because it would enable the respondents to express themselves in detail compared to a questionnaire where they could simply tick whatever would be seen as a correct answer. The responses from the interviewees represented the views of the other staff in the District who were not involved in the study.

\section{RESEARCH FINDINGS}

\section{Table 1: Showing the Roles of Language Usage in Human Resource Performance}

\begin{tabular}{lll}
\hline The role of language in human resource performance & $\mathbf{f}$ & $\mathbf{\%}$ \\
\hline Language usage promotes love among employees of a company. & 78 & 87 \\
\hline Proper language usage gives employees the zeal to do the work. & 65 & 72 \\
\hline Language usage promotes teamwork among employees. & 62 & 69 \\
\hline Language usage makes workers develop a positive attitude towards workers. & 70 & 78 \\
\hline Language usage makes employees have a sense of self-conviction. & 64 & 71 \\
\hline Language usage leads to the development of a culture for the institution. & 57 & 63 \\
\hline Language usage makes all the employees rejoice over the good performance of the institution. & 73 & 81 \\
\hline Language usage makes employees have a focus. & 55 & 61 \\
\hline Language usage makes employees develop a sense of collective responsibility. & 67 & 74 \\
\hline Language usage makes employees have a sense of belonging. & 59 & 66 \\
\hline Language usage promotes unity among employees. & 62 & 69 \\
\hline Language usage promotes harmony among employees. & 68 & 76 \\
\hline
\end{tabular}

Table 1 shows the various ways in which language usage affects human resource performance in Bududa local district government. According to Table 1 above, 78 (87\%) respondents agreed that if language could be used properly in Bududa local district government, it would promote love among the employees, thereby improving human resource performance. The respondents said that there are no conflicts where there is love and the employees focus on the achievement of the required goals. They continued to say that if there are no conflicts in an organisation, they concentrate on their work, hence increasing productivity. Out of a total number of 90 respondents, only 12 (3\%) objected to the view. This implies that there is a need for the Bududa Local district government authorities to put in place measures for proper language use to improve human resource performance.

A big number of $65(72 \%)$ respondents said that language usage gives employees the zeal to do the work. They said that if language could be used properly in Bududa local district government, it would contribute a lot to human resource performance. They said that the language used in an organisation motivates the employees, which in return improves their performance. This means that as one of the ways of improving human resource performance in Bududa Local district government, there is a need to consider proper language use. Only 25 (18\%) respondents out of 90 disagreed with the given view.

A relatively similar number of $62 \quad(69 \%)$ respondents said that an organisation's language promotes teamwork. They said that teamwork is crucial for the growth of any organisation. The respondents continued to say that if authorities in Bududa Local district government considered proper language; the employees would show a spirit of teamwork hence boosting human resource performance. Therefore, this means that authorities 
in Bududa Local district government need to consider proper language usage to improve human resource performance. Only $28(31 \%)$ out of 90 respondents objected to this view.

A slightly bigger number of $70(78 \%)$ respondents said that the company's language makes the employees have a positive attitude towards the work. They said that where the employees have a positive attitude, their performance is good but where they have a negative attitude, their performance is usually bad. The respondents who were interviewed said that if authorities in Bududa Local district government were to use the language strategy, they would improve human resource performance in the District. They said that a positive attitude improves human resource performance hence the success of the company. Only 20 (30\%) respondents out of 90 respondents disagreed with this view.

A total number of $64(71 \%)$ respondents said that the language used in an organisation makes the employees have self-conviction. They said in any organisation, language is a guiding factor. They said that employees feel convicted when they are about to do something contrary to the organisation's requirements because of the language used. The respondents said that if the authorities in Bududa Local district government were to use the language strategy, they would improve their human resource performance. Out of a total number of 90 respondents, only $26(29 \%)$ disagreed with this view.

Furthermore, 57 (63\%) respondents said that language usage makes an institution develop a particular culture. They said that culture is very important to any organisation. They said that if an organisation has a culture, all the employees must respect it. They said that makes them move in one direction hence improve human resource performance. The respondents said that if the authorities considered this in Bududa Local district government, they would improve their human resource performance. The respondents said that there is a need for the authorities in Bududa Local district government to consider using language as a strategy to improve their human resource performance. Out of a total number of 90 respondents, only $33(37 \%)$ disagreed with this view.

According to Table 1 above, 73(81\%) of the respondents said that language usage makes all the employees rejoice over the good performance. They said this is so because they feel each of them has had a contribution. The respondents said that if authorities in Bududa Local district government were to use a language strategy; they would improve on their human resource performance. They continued to say that authorities in the District must consider language usage among other strategies to improve on their human resource performance. Out of a total number of 90 respondents, only 17 (19\%) disagreed with this view.

A reasonable number of $55(61 \%)$ of the respondents said that the company's language makes the employees have a focus. They said that there is a way in which language makes people get focused on their work. They said this is because they have a target and mission to fulfil. Therefore, the respondents agreed that if authorities in Bududa local district government were to use language strategy; they would be able to improve on their human resource performance. They said that among all the District strategies to improve human resource performance, language usage should be considered. Out of a total number of 90 respondents, only 45 (39\%) respondents disagreed with this view.

A relatively big number of $67(74 \%)$ respondents said that language usage makes employees have a collective responsibility. They said that language usage makes all the employees feel responsible for whatever happens in the institution. Thus, if anything goes wrong, they are to share the blame. That is to say, there is no pinpointing fingers at individuals. On the other hand, if the institution 
makes an achievement, it is by all employees but not individuals. The respondents said that if authorities in Bududa Local district government were to use a language strategy; they would improve on their human resource performance. The respondents said that the Bududa District authorities should consider using this strategy to improve their human resource performance. Out of a total number of 90 respondents, only $23(26 \%)$ disagreed with this view.

A total number of $59(66 \%)$ respondents said that language usage makes employees have a sense of belonging. The respondents said that where there is proper language usage, people usually develop a sense of belonging. They do not consider themselves working for somebody or the government, but they consider themselves doing their work. They said this reduces bad vices like corruption, doing shoddy work, reporting late for duty etc. The respondents said that if authorities in Bududa Local district government were to use the language strategy; they would greatly improve their human resource performance. Out of 90 respondents, only $31(34 \%)$ disagreed with the view.

A fairly big number of $62(69 \%)$ respondents said that language usage promotes unity among an institution's employees, hence improving human resource performance. They said that where there is proper language usage, the employees are united, but they are disunited when it is not properly used. They said that good results are expected where the workers are united, but when they are not united, bad results are expected. Therefore, they said that if authorities in Bududa Local district government were to use a language strategy, they would improve on their human resource performance. They said that there is a need for the authorities in Bududa District to consider using language to improve their human resource performance. Out of 90 respondents, only $28(31 \%)$ disagreed with this view.
A total number of $68(76 \%)$ respondents said that language usage promotes harmony among a company's employees. The respondents said that there is usually harmony among the employees where there is proper language usage, but if there is improper language usage, there is always a lack of harmony among them. They said that where there is harmony, the performance is good, and there is a lack of harmony, the performance is usually bad. The respondents said that if authorities in Bududa Local district government were to use a language strategy; they would improve on their human resource performance. They suggested that the Bududa Local district government's leadership should consider using a language strategy to improve their human resource performance. Out of 90 respondents, only 22 (24\%) disagreed with this view.

\section{CONCLUSION}

Language is a gift from God. It cannot be bought or made by a human being. Language is very important in human life. According to research findings, language is very crucial in human resource performance. This, therefore, calls for a concerted effort to establish clear language usage. As organisations devise ways of improving human resource performance, the language used should not be left behind. Directors of organisations should endeavour to promote language usage in matters of human resource performance. Newly recruited employees should be trained in language use at the company. New employees should be made aware of the language required at their place of work. Once the employees have their unique language, there will be an improvement in human resource performance, hence increasing productivity of a company. 


\section{REFERENCES}

Allen, D., Lee, Y. T., \& Reiche, S. (2015). Global work in the multinational enterprise: New avenues and challenges for strategically managing human capital across borders. Journal of Management, 41(7), 2032-2035.

Barner-Rasmussen, W., Ehrnrooth, M., Koveshnikov, A., \& Mäkelä, K. (2014). Cultural and language skills as resources for boundary spanning within the MNC. Journal of International Business Studies, 45(7), 886-905.

Brannen, M. Y., Piekkari, R., \& Tietze, S. (2017). The multifaceted role of language in international business: Unpacking the forms, functions and features of a critical challenge to MNC theory and performance. In Language in International Business (pp. 139-162). Palgrave Macmillan, Cham.

Crowley, J. (2017, November 8). The importance of translating and localising your international $H R$ communications. Retrieved from https://www.p eoplehr.com/blog/2017/11/08/the-importanceof-translating-and-localising-your-internationalhr-communications/

Daniel, V. O. (2017). Politeness in Language. Lancaster University Press, UK.

Froese, F. J., Kim, K., \& Eng, A. (2016). Language, cultural intelligence, and inpatriate turnover intentions: Leveraging values in multinational corporations through inpatriates. Management International Review, 56(2), 283-301.

Harzing, A. W., \& Feely, A. J. (2008). The language barrier and its implications for HQ-subsidiary relationships. An International Journal of CrossCultural Management.

Human Resource Online. (2018, August 1). How the language you speak at work affects future company strategy. Retrieved from https://www. humanresourcesonline.net/how-the-language- you-speak-at-work-affects-future-companystrategy.

HumanResourcesEdu. (2021). What is Human Resource? Retrieved From https://www.humanr esourcesedu.org/what-is-human-resources/.

Impraise. (2020). How language impacts your company culture. Retrieved from https://www.i mpraise.com/blog/how-language-impacts-yourcompany-culture.

Itani, S., Järlström, M., \& Piekkari, R. (2015). The meaning of language skills for career mobility in the new career landscape. Journal of world business, 50(2), 368-378.

Jones, R. (2010, October 19). Redefining the Language of HR. Retrieved from https:/www.hrexchangenetwork.com/hr-talentmanagement/articles/redefining-the-languageof-hr.

Latukha, M., Doleeva, A., Järlström, M., Jokinen, T., \& Piekkari, R. (2016). Does corporate language influence career mobility? Evidence from MNCs in Russia. European Management Journal, 34(4), 363-373.

McMunn, R. (2017, August 7). 3 Ways Language Training Benefits Your Business. Retrieved from https://www.entrepreneur.com/article/296242.

Neeley, T. (2019). The language of global success: How a common tongue transforms multinational organisations. Princeton University Press.

Peltokorpi, V. (2015). Corporate language proficiency and reverse knowledge transfer in multinational corporations: Interactive effects of communication media richness and commitment to headquarters. Journal of International Management, 21(1), 49-62.

Peltokorpi, V. (2017). Absorptive capacity in foreign subsidiaries: The effects of languagesensitive recruitment, language training, and 
interunit knowledge transfer. International Business Review, 26(1), 119-129.

Peltokorpi, V., \& Vaara, E. (2014). Knowledge transfer in multinational corporations: Productive and counterproductive effects of language-sensitive recruitment. Journal of International Business Studies, 45(5), 600-622.

Peltokorpi, V., \& Vaara, E. (2017). Language policies and practices in wholly owned foreign subsidiaries: A recontextualisation perspective. In Language in International Business (pp. 93138). Palgrave Macmillan, Cham.

Peltokorpi, V., \& Yamao, S. (2017). Corporate language proficiency in reverse knowledge transfer: A moderated mediation model of shared vision and communication frequency. Journal of World Business, 52(3), 404-416.

Piekkari, R., \& Tietze, S. (2012). Language and international human resource management. In Handbook of Research in International Human Resource Management(Second Edition). Edward Elgar Publishing.

Piekkari, R., Welch, D., \& Welch, L. S. (2014). Language in international business: The multilingual reality of global business expansion. Edward Elgar Publishing.

Presbitero, A. (2020). Foreign language kill, anxiety, cultural intelligence and individual task performance in global virtual teams: A cognitive perspective. Journal of International Management, 26(2), 100729.

Pudelko, M., \& Tenzer, H. (2019). Boundaryless careers or career boundaries? The impact of language barriers on academic careers in international business schools. Academy of Management Learning \& Education, 18(2), 213240.
Richard. (2019, February 19). English for HR Managers: Jargon. Retrieved from London School of English and Foreign Languages, https://www.londonschool.com/blog/english-hrmanagers-jargon/.

Schomaker, M. S., \& Zaheer, S. (2014). The role of language in knowledge transfer to geographically dispersed manufacturing operations. Journal of International Management, 20(1), 55-72.

Selmer, J., \& Lauring, J. (2015). Host country language ability and expatriate adjustment: The moderating effect of language difficulty. The International Journal of Human Resource Management, 26(3), 401-420.

Summa Linguae Technologies. (n.d.). Language Support: The fourth wheel for a diverse, ubiquitous workforce. Retrieved from https://summalinguae.com/business/languagesupport-the-fourth-wheel-for-a-diverseubiquitous-workforce/.

Tenzer, H., \& Pudelko, M. (2015). Leading across language barriers: Managing language-induced emotions in multinational teams. The Leadership Quarterly, 26(4), 606-625.

Tenzer, H., \& Pudelko, M. (2017). The influence of language differences on power dynamics in multinational teams. Journal of World Business, 52(1), 45-61.

Tenzer, H., Terjesen, S., \& Harzing, A. W. (2017). Language in international business: A review and agenda for future research. Management International Review, 57(6), 815-854.

Zhang, L. E., \& Peltokorpi, V. (2016). Multifaceted effects of host country language proficiency in expatriate cross-cultural adjustments: a qualitative study in China. The International Journal of Human Resource Management, 27(13), 1448-1469. 